\title{
Analysis of the Recycling Sector in Intermediate Cities. Study Case - Neiva, Colombia
}

INGENIERÍA INDUSTRIAL

\section{Análisis del sector reciclador en ciudades intermedias. Estudio de caso municipio de Neiva, Colombia}

\author{
Christian Valderrama $^{1 \S}$, Juan D. Ortiz ${ }^{1}$, Maria M. Usa ${ }^{1}$, Oscar I. Borrero ${ }^{1}$ \\ ${ }^{1}$ Universidad Nacional Abierta y a Distancia, Escuela de Ciencias Agrícolas, Pecuarias y del Medio \\ Ambiente, Neiva, Colombia
}

§Christian.valderrama@unad.edu.co,jdortizav@unadvirtual.edu.co,mmusap@unadvirtual.edu.co, oiborreroi@unadvirtual.edu.co

Recibido: 14 de enero de 2020 - Aceptado: 21 de abril de 2020

\begin{abstract}
The economic activity of recycling belongs to an unfortunate and marginalized segment of society in Colombia. This fact translates in high rates of informality and a general perception about people that work in this activity, which come usually from extreme poverty, burdened by discrimination, drug addiction, and rejection. The goal of this research was to determine the most significant factors impacting levels of society and economics. For this purpose, we carried out a mixed analysis in the chain of the recycling sector in Neiva, an intermediate city. Because of the informality of waste pickers' union, official information and field survey were conducted to identify the waste commercialization establishments. The collection and transportation process were identified, and a survey was applied to 50 waste pickers and ten recycling companies. Seventy-two percent of the population is constituted by male gender, older than 25 years, in an unsafe condition, and with labor intensity of 8 hours per day (average). On the other hand, forty percent of companies have labor-related personnel, which confirms a high level of informality in the sector. The most commercialized product is cardboard, and the vast majority only purchase and commercialize the material.
\end{abstract}

Keywords: Commerce, Recycling, Solid waste, Vulnerability, Waste picker.

\section{Resumen}

El reciclaje es una actividad del sector económico menospreciado y marginado en Colombia, con altos índices de informalidad, además de ser catalogado como un trabajo ejecutado por personas que viven en extrema pobreza, agobiados por la discriminación, drogadicción y rechazo. En este estudio se realizó una investigación en donde se abordó la cadena del sector económico del reciclaje en una ciudad intermedia como es el municipio de Neiva, con el propósito de determinar los factores de mayor impacto a nivel social y económico. Debido a la alta informalidad del gremio, se realizó un estudio de carácter mixto, que permitió cruzar la información oficial con un levantamiento en 
campo para identificar los establecimientos de comercialización de residuos. Se identificó el proceso de recolección y transporte de residuos, se aplicó una encuesta a 50 recuperadores y a 10 empresas de reciclaje. Se encontró que un $72 \%$ de la población pertenece al género masculino, con una población mayor de 25 años en condición de vulnerabilidad, en donde trabajan en promedio 8 horas al día; Por otro lado, se identificó que solo un $40 \%$ de las empresas cuenta con personal vinculado laboralmente, presentándose una alta informalidad en el sector, el producto de mayor comercialización es el cartón y la gran mayoría solo realiza compra y comercialización del material.

Palabras clave: Comercio, Reciclaje, Recuperador, Residuos sólidos, Vulnerabilidad.

\section{Introduction}

The use and management of wastes face significant challenges posed by rapid urbanization and population growth. Currently, an overall waste generation rate ranges from 0.11 to $4.54 \mathrm{~kg}$ per person per day ${ }^{(1)}$, which implies an increase of up to 3.4 billion metric tons over the next 30 years $^{(2)}$. This fact is generated from an economic model of high consumption of goods and high production of waste as well. The inadequate disposal of wastes is causing degradation in different natural resources $^{(3)}$ and the destruction of landscapes of urban ecosystems. Unhealthy, loss of water surface and soil quality, acute respiratory infections, and greenhouse gas emissions are provoked by this situation ${ }^{(4)}$ which affects the social and economic sector ${ }^{(5)}$. Replacing the model of disposal of waste by one that focuses on reuse and getting of value ${ }^{(6)}$.

In Latin America and most developing countries, intermediate cities with a population ranging from 50,000 to 1 million people serve as a link between rural and urban areas. These cities account for about $20 \%$ of the world's population (7). Nowadays, the vast majority of these cities present difficulties in solid waste management. There are limitations in knowledge associated with factors that influence adequate management ${ }^{(8)}$ such as consumption habits, collection coverage, composition, rare selective collection $^{(9)}$. Besides, achieving financial sustainability and public-private cooperation is difficult $^{(10)}$. Their management continues to be the final disposal without any type of treatment
(11,12), generating environmental, social, and cultural impacts ${ }^{(13)}$ in regions because of the large volumes that are generated.

From 15 million waste pickers in the world, there are 4 million in South America with approximately 229,568 workers in Brazil (14), which generate a benefit to legal waste management. It provided a livelihood for about $1 \%$ of the urban population in Latin America ${ }^{(15,16)}$, where the work of these people represents almost $30 \%$ of the recovery process of Valuable Solid Waste in Latin America, Asia, and Africa $(17,18)$.

Although governments in Latin America actively support the organization of informal waste pickers through the creation of structures, legislation, and funding measures to support the solidarity economy ${ }^{(19)}$. There are still shortcomings in various aspects, including negative social perceptions and community rejection of this activity ${ }^{(20)}$.

In Latin American countries where WIEGO (Women in Informal Employment: Globalizing and Organizing) conducted this research, waste pickers that worked in the informal economy do not have safe access to recyclable materials and tend to work in precarious, unhealthy, and hazardous conditions ${ }^{(21)}$. In the majority of the cases, the informal recycling activity makes without personal protection equipment to handle urban waste, getting into permanent contact with toxic or dangerous health care waste ${ }^{(12,21,22)}$. In consequence, diseases associated with respiratory infections, eye infections, and 
stomach problems, among other effects ${ }^{(14,23)}$, are caused. Different muscular-skeletal disorders are also associated with these people.

This project aims to diagnose the current state of the recycling chain in the intermediate city of Neiva. To determine factors that influence the commercialization of recyclable waste at the local level through both identification and research of this sector through the method of direct observation and an information collection survey. Results from this study allow constituting a line of reference on the behavior of this sector and how culture and innovation can transform the city.

\section{Methodology}

This research was developed under a descriptive exploratory scope. The target population was informal waste pickers and cooperatives or recycling companies in the city of Neiva - Huila.

Due to the lack of information on the number of waste pickers in the study area, there was no prior choice of respondents through statistical sampling, so non-probability sampling was used. The methodology was based on the characterization through observation and application of a survey, which allowed for an understanding of the social and economic conditions of waste pickers and the operational structure of recycling companies in the city.

The techniques of collection and construction of information obtained by the exploratory tool of observation allowed compiling information employing official sources at the local level related to the chain of the recycling. The zones and establishments where collected materials are commercialized were identified using a field route by the ten (10) communes within the urban helmet of the city. From the conducted data analysis to determine companies legally registered to December 2017 and those that operate informally, twenty-eight legal and 15 informal traders were found. Finally, the waste pickers monitored by the neighborhoods and points of purchase and sale of recycled material to identify the behavior, collection process, and sale of waste.

The application of the semi-structured in-person survey was carried out. Fifty (50) waste pickers in the areas were surveyed where the recovered material marketed. The survey consisted of 40 questions that identified waste pickers' demographic data (education level, income, transport vehicle, and collection methods).

On the other hand, due to poor reception and support from the waste picker business sector, a non-probabilistic survey was conducted targeting ten (10) constituted businesses that supported the research. It applied the tool to identify the labor and economic conditions associated with the commercialization of waste in the city. Finally, a statistical software was used for the evaluation and interpretation of data and content analysis.

\section{Results and discussion}

\subsection{Waste pickers}

A survey conducted among a population of 50 trade waste pickers identified within the entire urban area of the city of Neiva. Seventy-two percent of the waste pickers surveyed were found male genre (Table 1). The elderly population is the most predominant in the development of this activity (38\%) and followed by the adult population (30\%). The highest level of schooling is Primary School (82\%) and Middle Secondary (14\%). Homeownership $(68 \%)$ and renting $(26 \%)$ predominated in the survey. They are responsible for between 1-3 children (42\%) and more than three (3) children $(42 \%)$. 
A similar trend in socio-demographic characteristics observed in Colombia ${ }^{(24,25)}$ and Latin America, in countries such as Brazil ${ }^{(26)}$, Argentina $^{(27)}$, and Chile $^{(20)}$, where the base population of this marketing chain identified as the most vulnerable.

Table 1. Demographic characteristics of the recycling population $(N=50)$

\begin{tabular}{ccc}
\hline \multirow{2}{*}{ Features } & \multicolumn{2}{c}{ Population } \\
\cline { 2 - 3 } Gender (\%) & 28 & 72 \\
& Age range (\%) & \\
$12-18$ & 0 & 10 \\
$14-26$ & 6 & 16 \\
$27-59$ & 14 & 16 \\
$>60$ & 8 & 30 \\
\multicolumn{3}{c}{ Grade of schooling (\%) } \\
None & 2 & \\
Primary School & 16 & 2 \\
Middle School & 10 & 66 \\
\multicolumn{4}{c}{ Children in charge } \\
0 & 0 & 16 \\
$1-3$ & 10 & 32 \\
$<3$ & 18 & 24 \\
& Type of housing (\%) \\
Own & 24 & 44 \\
Family & 2 & 4 \\
Leased & 6 & 20 \\
\hline
\end{tabular}

Most of the population was observed been carrying out this activity for more than five (5) years $(58 \%)$ or between $1-5$ years $(28 \%)$. It was highlighted that it is their only form to work $(86 \%)$ and allows them to provide a livelihood for the family. Similarly, a large part of the population stated that they work three (3) days a week (36\%), adjusting to the frequency of waste collection in one sector, the other population collects seven (7) days a week (32\%), and six(6) days a week $(12 \%)$ in different areas of the city.
It guaranteed a quota of daily income because their profits depend on the daily market price of the product ${ }^{(27)}$ (Table 2).

Table 2. Socioeconomic characteristics of the waste pickers $(N=50)$

\begin{tabular}{cc}
\hline Time in the profession & $\mathbf{N}(\%)$ \\
\hline 1 year & 14 \\
$1-5$ years & 28 \\
< 5 years & 58 \\
Reason for the activity & \\
Only work & 86 \\
Additional income & 10 \\
Requires another job to live & 4 \\
$\quad$ Days worked & \\
1 & 4 \\
2 & 2 \\
3 & 36 \\
4 & 8 \\
5 & 6 \\
6 & 12 \\
7 & 32 \\
\hline
\end{tabular}

From the relationship between working hours and incomes (Figure 1), a person who works between 4 and 6 hours per day (38\%) earns an income that ranges from $\$ 11,000$ to 15,000 Colombian pesos (48\%), between 6 and 8 hours per day (28\%) generates on average $\$ 16,000$ to 20,000 Colombian pesos (16\%), and $22 \%$ from survey respondents work between 8 and 10 hours per day and earns between $\$ 21,000$ to 40.000 Colombian pesos $(6 \%)$.

Although this work requires a high physical effort to achieve the minimum daily wage, the characteristics of Neiva to being an intermediate city allow than the distances travelled to collect and deliver their product was less than $10 \mathrm{~km}$. Being a market that could be attractive with a social-economic model for this population if it applies hybrids models between the formal and informal sectors ${ }^{(28)}$, optimizes the transport enhancement ${ }^{(29)}$, and improve the logistic of recovery ${ }^{(30,31)}$. 


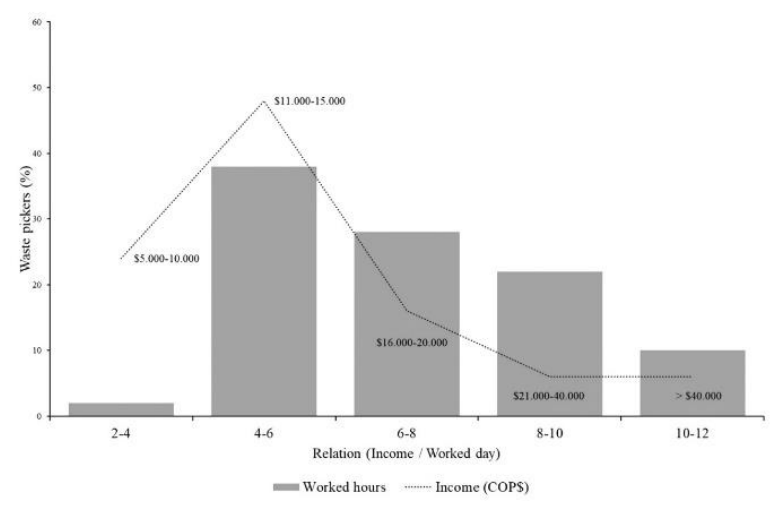

Figure 1. Relationship of income per hours worked in the recycling activity

A large part of this population transports recyclable material through the rented cart (56\%), bicycle (18\%), and cart (14\%) (Table 3). The waste transported is a critical event since factor in the generation of income is essential ${ }^{(32)}$ The intermediary forces the collector to operate under their economic model, renting vehicles, limiting opportunities to generate profit ${ }^{(20)}$, causing an increase in social inequity, and the unequal distribution of income ${ }^{(16)}$.

Table 3. Recovered waste transport vehicles

\begin{tabular}{cc}
\hline Way of transport & Percentage (\%) \\
\hline Foot trolley & 56 \\
Tricycle & 10 \\
Motorcycle trolley & 2 \\
Cart & 14 \\
Other (walking, & 18 \\
cycling) & 18 \\
\hline
\end{tabular}

A critical result found in the handling of waste since $100 \%$ of the sample survey respondents answered that they removed the materials manually without any personal protective equipment. Only $22 \%$ of them have received training or talks about the handling and classification of solid waste, the rest of active workers $(78 \%)$ are unaware of the different physical, chemical, and ergonomic risks ${ }^{(3,33)}$. That deteriorates their health and makes them potential transmitters of biological diseases by being exposed to microorganisms related to Acute Diarrhoeal Diseases ${ }^{(12,34)}$, Acute Respiratory Infections ${ }^{(34)}$.

\subsection{Recycling companies}

This tool applied to 10 companies in the city of Neiva and factors associated with the socioeconomic aspect of the recycling chain were identified. The owners of the recycling companies have primary schooling degrees (60\%) and secondary school (40\%). Most of the business sector has been operating for more than five (5) years $(50 \%)$ and between $1-5$ years (40\%) (Table 4). It can seem that most of the recycling companies in Neiva are family-owned, where most of them have 1-3 employees (50\%).

Table 4. Demographic characteristics of recycling companies $(N=10)$

\begin{tabular}{cc}
\hline Features & $\mathbf{N}(\%)$ \\
\hline \multicolumn{2}{c}{ Grade of schooling $(\%)$} \\
None & 0 \\
Primary School & 0 \\
Secondary School & 40 \\
University & 60
\end{tabular}

Operating time

$\begin{array}{cc}<1 \text { year } & 10 \\ 1-5 \text { years } & 40 \\ >5 \text { years } & 50\end{array}$

\section{Recycling Family}

\begin{tabular}{ll}
0 & 40 \\
$1-3$ & 50 \\
$>3$ & 10 \\
\multicolumn{2}{c}{ Related partners } \\
0 & 10 \\
$1-3$ & 60 \\
$>3$ & 30
\end{tabular}

From Table 5, carton (22\%) is the product with the highest commercialization in Neiva, followed by Polyethylene Terephthalate - PET (18\%), Low Density Polyethylene - LDPE (16\%), High Density Polyethylene - HDPE (14\%), paper or file (13\%), and metals (10\%). 
Table 5. Recovered products with greater commercialization

\begin{tabular}{cc}
\hline Recovered material & Percentage (\%) \\
\hline Carboard & 22 \\
Plastic (PET) & 18 \\
Plastic (LDPE) & 16 \\
Pasta (HDPE) & 14 \\
Paper & 13 \\
Metals & 10 \\
Glass & 7 \\
\hline
\end{tabular}

Crushing and granulation processes become a preferred option from some buyers in order to obtain a higher profit in the commercialization of waste. Ninety percent of survey respondents answered NOT to transform the bought material and only $10 \%$ responded to carry out this procedure.

The factor of tons of waste purchased daily observed in Table 6 is a vital variant to take into account when estimating the average weekly amount of waste generated in the city, with $50 \%$ of respondents saying they buy between 1 and 5 tons per week, $40 \%$ buying 6 to 15 tons. Only $10 \%$ answering to buy between 16 and 30 tons.

Table 6. The weekly average of the material sold.

\begin{tabular}{cc}
\hline $\begin{array}{c}\text { Marketed material } \\
\text { (Tons) }\end{array}$ & Percentage (\%) \\
\hline 1 a 5 & 50 \\
6 a 15 & 40 \\
$16-30$ & 10 \\
\hline
\end{tabular}

It found that $40 \%$ of the wholesale respondents market biweekly, the middlemen or retailers, responded to sell their products weekly (30\%) and daily (30\%). It found that $40 \%$ of the respondents have an organized group or staff for recycling, and $60 \%$ responded that they do not have any organization with the waste picker population.

Finally, it is necessary to design government policies to an informal economy that allows modernizing the waste management system to increase the rate of recycling and income (35) based on transitional models. It will let be inclusive ${ }^{(36,37)}$, voluntary, legal, structured, and cooperative production approaches ${ }^{(20)}$, relying on local policies to increase productivity ${ }^{(25)}$, reduce precariousness $^{(38)}$, optimize mobilization ${ }^{(39)}$, through the social economy. It will allow the local reinsertion and development of this economic sector, raising the income and quality of life of waste pickers.

\section{Conclusions}

This article sought to provide information on the socio-economic working conditions of informal waste pickers in an intermediate city in Colombia, highlighting significant deficiencies associated with the development of their labor and survival activities such as the lack of technical, social, and financial support. It will allow them to plan their labor growth to improve occupational health and safety conditions by obtaining transport vehicles and personal protection equipment to reduce effort and increase their incomes.

Neiva, being an intermediate city can generate an opportunity to organize and optimize the recycling sector because the distances between residential areas are short, the maximum distance to the industrial zone in the urban area does not exceed $10 \mathrm{~km}$. It is crucial to enhance the waste picker role through the social economy with the purpose to eradicate the intermediate people that take advantage of their vulnerability, their lack of collection equipment, and their household location.

Concerning the role of recycling companies, the evidence obtained indicates that their development is associated with the creation of family businesses, where more than half only manage three (3) formal employees and half have maintained their economic activity for 
more than five (5) years. Currently, they based the economic model on the purchase and sale of waste regardless of its origin, it creates wealth for the city but at the same time causes informality to be a critical factor in income generation.

\section{References}

(1) Kaza S, Bhada-Tata P, Lisa Y, Van Woerden F. What a Waste 2.0: A Global Snapshot of Solid Waste Management to 2050. Urban Development. The World Bank; 2018. 292 p. Available from: https://doi.org/10.1596/978-1-4648-13290 .

(2) Hoornweg D, Bhada-Tata P. Urban Development - What a Waste: A Global Review of Solid Waste Management. The World Bank, editor. Washington; 2012 [Consulted 2018/03/25]. Report No.: 15. Available from: https://openknowledge.worldbank.org/han dle/10986/17388.

(3) Gómez-Correa JA, Agudelo-Suárez AA, Ronda-Pérez E. Condiciones Sociales y de Salud de los Recicladores de Medellín. Rev Salud Pública. 2008;10(5):706-15. Doi: $\quad 10.1590 / \mathrm{S} 0124-$ 00642008000500003.

(4) Vázquez-Rowe I, Kahhat R, LarreaGallegos G, Ziegler-Rodriguez K. Peru's road to climate action: Are we on the right path? The role of life cycle methods to improve Peruvian national contributions. Sci Total Environ. 2019;659:249-66. Doi: 10.1016/j.scitotenv.2018.12.322.

(5) Valdivia-Alcalá R, Abelino-Torres G, López-Santiago MA, Zavala-Pineda MJ. Valoración económica del reciclaje de desechos urbanos. Rev Chapingo Ser Ciencias For y del Ambient.
2012;18(3):435-47.

Doi:

10.5154/r.rchscfa.2010.07.044.

(6) Lett LA. Las amenazas globales, el reciclaje de residuos y el concepto de economía circular. Rev Argent Microbiol. 2014;46(1):1-2. Doi: 10.1016/S03257541(14)70039-2.

(7) Iglesias BM. Intermediary cities in the territorial integration of the Global South. Rev CIDOB d'Afers Int. 2016;2016(114):109-32.

(8) Guerrero LA, Maas G, Hogland W. Solid waste management challenges for cities in developing countries. Waste Manag. 2013;33(1):220-32. Doi: 10.1016/j.wasman.2012.09.008.

(9) Hettiarachchi H, Ryu S, Caucci S, Silva R. Municipal Solid Waste Management in Latin America and the Caribbean: Issues and Potential Solutions from the Governance Perspective. Recycling. 2018;3(2):19. Doi: 10.3390/recycling3020019.

(10) Ramírez-Vargas CA, Paredes D, Guerrero J. Sostenibilidad financiera y económica de plantas de manejo de residuos sólidos urbanos en Colombia. Ing Y Compet. 2014;16(2):65-77.

Doi: 10.25100/iyc.v16i2.3684.

(11) Bezama A, Aguayo P, Konrad O, Navia $\mathrm{R}$, Lorber KE. Investigations on mechanical biological treatment of waste in South America: Towards more sustainable MSW management strategies. Waste Manag. 2007;27(2):228-37.Doi: 10.1016/j.wasman.2006.01.010.

(12) Resende V, Cruvinel N, Rava Zolnikov T, Bashash M, Marques CP, Scott JA. 
Waterborne diseases in waste pickers of Estrutural, Brazil, the second largest openair dumpsite in world. Waste Manag. 2019;99:71-8.

Doi:

10.1016/j.wasman.2019.08.035.

(13) Ballesteros VL, Yicenia ;, Urrego C, Botero Botero S, Arango YL. Factores de riesgo biológicos en recicladores informales de la ciudad de Medellín, 2005. Rev Fac Nac Salud Pública. 2008;26(2):169-177.

(14) Mol MPG, Pereira AF, Greco DB, Cairncross S, Heller L. Assessment of work-related accidents associated with waste handling in Belo Horizonte (Brazil). Waste Manag Res. 2017;35(10):1084-92. Doi: 10.1177/0734242X17722209.

(15) Gutberlet J. Informal and Cooperative Recycling as a Poverty Eradication Strategy. Geogr Compass. 2012;6(1):19$34 . \quad$ Doi: $\quad 10.1111 / \mathrm{j} .1749-$ 8198.2011.00468.x.

(16) Wilson DC, Rodic L, Scheinberg A, Velis CA, Alabaster G. Comparative analysis of solid waste management in 20 cities. Waste Manag Res. 2012;30(3):237-54. Doi: $10.1177 / 0734242 X 12437569$.

(17) Botello-Álvarez JE, Rivas-García P, Fausto-Castro L, Estrada-Baltazar A, Gomez-Gonzalez R. Informal collection, recycling and export of valuable waste as transcendent factor in the municipal solid waste management: A Latin-American reality. J Clean Prod. 2018;182:485-95. Doi: 10.1016/j.jclepro.2018.02.065.

(18) Gutberlet J. Cooperative urban mining in Brazil: Collective practices in selective household waste collection and recycling. Waste Manag .2015;45:22-31. Doi: 10.1016/j.wasman.2015.06.023.
(19) Castelao-Caruana ME, Srnec CC. Public Policies Addressed to the Social and Solidarity Economy in South America. Toward a New Model? Voluntas. 2013;24:713-32. Doi: 10.1007/s11266012-9276-y.

(20) Navarrete-Hernandez P, NavarreteHernandez N. Unleashing Waste-Pickers' Potential: $\quad$ Supporting Recycling Cooperatives in Santiago de Chile. World Dev. 2018;101:293-310. Doi: 10.1016/j.worlddev.2017.08.016.

(21) Maldonado AR. La situación de los derechos humanos de la comunidad recicladora en América Latina: un reclamo urgente por respeto a través de estándares internacionales [Internet]. México D.F.; 2019 [Consulted 2019/12/23]. p. 11. Available from: https://www.wiego.org/node/7794.

(22) Ziraba AK, Haregu TN, Mberu B. A review and framework for understanding the potential impact of poor solid waste management on health in developing countries. Archives of Public Health. 2016;74:55 Doi: 10.1186/s13690-0160166-4.

(23) Zolnikov TR, da Silva RC, Tuesta AA, Marques CP, Cruvinel VRN. Ineffective waste site closures in Brazil: A systematic review on continuing health conditions and occupational hazards of waste collectors. Waste Manag. 2018;80:26-39. Doi: 10.1016/j.wasman.2018.08.047.

(24) Martínez L, Zuluaga B, Estrada D. The socioeconomic conditions of recyclers: Census data in Cali, Colombia. Data Br. 2019;23:103695.

Doi: 10.1016/j.dib.2019.01.043. 
(25) Tovar LF. Formalización de las organizaciones de recicladores de oficio en Bogotá: reflexiones desde la economía popular. Revista de Ciencias Sociales. 2018;62:39-63. Doi: 10.17141/iconos.62.2018.3230.

(26) Castilhos Junior AB, Ramos NF, Alves CM, Forcellini FA, Graciolli OD. Recyclable material waste pickers: An analysis of working conditions and operational infrastructure in the south, southeast and northeast of Brazil. Cienc e Saude Coletiva. 2013;18(11):3115-24. Doi: $\quad 10.1590 /$ S141381232013001100002 .

(27) Parizeau K. When Assets are Vulnerabilities: An Assessment of Informal Recyclers' Livelihood Strategies in Buenos Aires, Argentina. World Dev. 2015;67:161-73.

Doi: 10.1016/j.worlddev.2014.10.012.

(28) Padilla AJ, Trujillo JC. Waste disposal and households' heterogeneity. Identifying factors shaping attitudes towards sourceseparated recycling in Bogotá, Colombia. Waste Manag. 2018;74:16-33. Doi: 10.1016/j.wasman.2017.11.052.

(29) Rebehy PCPW, Costa AL, Campello CAGB, de Freitas Espinoza D, Neto MJ. Innovative social business of selective waste collection in Brazil: Cleaner production and poverty reduction. J Clean Prod. 2017;154:462-73. Doi: 10.1016/j.jclepro.2017.03.173.

(30) Ibáñez-Forés V, Bovea MD, CoutinhoNóbrega C, de Medeiros-García HR, Barreto-Lins R. Temporal evolution of the environmental performance of implementing selective collection in municipal waste management systems in developing countries: A Brazilian case study. Waste Manag. 2018;72:65-77. Doi: 10.1016/j.wasman.2017.10.027.

(31) Franca LS, Ribeiro GM, Chaves G de LD. The planning of selective collection in a real-life vehicle routing problem: A case in Rio de Janeiro. Sustain Cities Soc. 2019;47:101488.Doi:

10.1016/j.scs.2019.101488.

(32) Conke LS. Barriers to waste recycling development: Evidence from Brazil. Resour Conserv Recycl. 2018;134:12935. Doi: 10.1016/j.resconrec.2018.03.007.

(33) Fattor MV, Vieira MGA. Application of human HAZOP technique adapted to identify risks in Brazilian waste pickers' cooperatives. J Environ Manage. 2019;246:247-58. Doi: 10.1016/j.jenvman.2019.05.128.

(34) Schlosser O, Robert S, Noyon N. Airborne mycotoxins in waste recycling and recovery facilities: Occupational exposure and health risk assessment. Waste Manag. 2020;105:395-404.

Doi: 10.1016/j.wasman.2020.02.031.

(35) Ferronato N, Ragazzi M, Gorritty Portillo MA, Gabriela E, Lizarazu G, Viotti P, et al. How to improve recycling rate in developing big cities: An integrated approach for assessing municipal solid waste collection and treatment scenarios. Environ Dev. 2019;29:94-110. Doi: 10.1016/j.envdev.2019.01.002.

(36) Lino FAM, Ismail KAR. Analysis of the potential of municipal solid waste in Brazil. Environ Dev. 2012;4:105-13. Doi: 10.1016/j.envdev.2012.08.005. 
(37) Magni AAC, Günther WMR. Cooperativas de catadores de materiais recicláveis como alternativa à exclusão social e sua relação com a população de rua. Saude e Soc. 2014;23(1):99-109. Doi: 10.1590/S0104-12902014000100011.

(38) O' Hare P. 'The landfill has always borne fruit': precarity, formalisation and dispossession among Uruguay's waste pickers. Dialect Anthropol. 2018;43:3144. Doi: 10.1007/s10624-018-9533-6.

(39) Sorroche S. Experiências replicáveis. Análise das vinculações entre cooperativas de recicladores, agências estatais e ONGs na Grande Buenos Aires. Rev Estud Soc. 2017;61:58-68.

Doi: 10.7440/res61.2017.05. 